\title{
Enhancing Language Teaching and Learning by Keeping Individual Differences in Perspective
}

\author{
Suriati Sulaiman \& Tajularipin Sulaiman \\ Faculty of Educational Studies, Universiti Putra Malaysia, Malaysia \\ E-mail: tajulas@putra.upm.edu.my
}

\begin{abstract}
Learners differ from each other in many ways particularly in cognitive abilities. These factors eventually affect their learning abilities. Thus teachers should look into learner differences in intelligence before designing a teaching and learning program for them. Gardner proposed a much broader view of the definition of intelligence than a number of other theorists with his theory of multiple intelligences. The important of the idea of multiple intelligences in education lies in the fact that learners vary in their abilities, and thus teachers need to find out the best strategies to use related to their variations, or to develop programs that instruct students in different domains. This paper attempts to provide a brief overview of the eight multiple intelligences connected with Howard Gardner's theory. The article also suggests some ways for teachers to incorporate the intelligences into their daily lesson planning for practical use in language teaching and learning.
\end{abstract}

Keywords: Language learning, Individual differences

\section{Introduction}

All learners are individuals with unique patterns of strengths and weaknesses. They differ greatly in cognitive abilities. Some learners learn complex classroom materials quickly and easily, whereas others struggle to master basic concepts and skills. The idea that people vary in cognitive abilities particularly intelligence has been discussed for a long time. Most early theories about the nature of intelligence include one or more of the following three components: (1) the capacity to learn, (2) the total knowledge a person has acquired, and (3) the ability to adapt successfully to new situations and the environment in general. Traditionally, the concept of intelligence refers to problem solving skills and the ability to adapt to and learn from life's everyday experiences. However, intelligence is an abstract, broad concept which has generated controversy and heated debate (Birney et al., 2005; Steinberg, 2006). Thus, it is not surprising that there are many different ways to define it and even there are many ways to measure it. No wonder there are many terms used to refer to individual's intelligence such as intelligence quotient (IQ), emotional quotient (EQ), and multiple intelligences. The knowledge of multiple intelligences theories particularly Gardner's (2004) theory of multiple intelligences (MI) should prove very helpful in English language teaching and learning as it gives ways to enhance teaching and learning practices generally by designing integrated teaching strategies and diverse learning activities that take into account of individual learner differences in intelligence, learning styles and learning preferences.

\section{Theories of Multiple Intelligences}

Since intelligence is a very broad concept, psychologists argue the structure of intelligence either it is a general ability or a number of specific abilities (Santrock, 2008). Some psychologists such as Binet and Stern focus on a concept of general intelligence, which Stern calls intelligence quotient (IQ). David Wechsler believes that intelligence is a person's general intelligence, and verbal and performance intelligences. His view was developed from the ideas of Charles Spearman (1927), who claims that people have both a general intelligence, which is called $g$, and a specific type of intelligence, which he calls $s$. Others define intelligence as a number of specific intelligences as proposed by Thurstone (1938). According to him, people have seven specific abilities, which he calls primary abilities: verbal comprehension, number ability, word fluency, spatial visualization, associative memory, reasoning, and perceptual speed.

Quite recently, an increasing number of studies are looking for specific types of intelligence (Gregory, 2007). Robert J. Sternberg (1986, 2004, and 2006) has introduced the triarchic theory of intelligences, which proposes that intelligence comes in three different forms: analytical, creative, and practical. Analytical intelligence involves the ability to analyze, judge, evaluate, compare, and contrast. Creative intelligence consists of the ability to create, design, invent, originate, and imagine. Practical intelligence focuses on the ability to use, apply, implement, and put into practice.

According to Sternberg (2002), learners with different triarchic intelligences look different in school. Learners with high analytic ability tend to be favored in conventional schools. They often do well in class in which the 
teacher lectures and gives objective tests. They typically get good grades, do well in traditional IQ tests and the SAT, and later gain admission to competitive colleges or universities. Learners who are high in creative intelligence often are not in the top rank of their class. Creatively intelligent learners might not conform to teachers' expectations about how assignments should be done. They normally give unique answers, for which they might get reprimanded or marked down. Learners, who are practically intelligent are like learners who are high in creative intelligence. They often do not relate well to the demands of school. However, they frequently do well outside the classroom and have good social skills.

Sternberg (2004) stresses that only few instructional tasks are purely analytic, creative, or practical. Most tasks require a combination of these intelligences. Sternberg believes that it is important for classroom instruction to give students an opportunity to learn through all these types of intelligences (Santrock, 2008).

Some psychologists insist that intelligence includes several separate mental abilities (Gardner, 2004). Howard Gardner (1993, 1999, 2000 and 2004) suggests that there are at least eight different abilities, or intelligences, that are relatively independent of one another. Gardner's perspective presents the possibility that most, and quite possibly all, of the learners may be quite intelligent in one way or another. Some learners may show exceptional promise in language, others may be talented in music, and still others may be able to learn mathematics more easily than their classmates.

The important of the idea of multiple intelligences in education lies in the fact that learners vary in their abilities, and thus teachers need to find out the best strategies to use related to their variations, or to develop programs that instruct the learners in different domains.

To help learners identify their own strength and weakness, or to help them in the choice of how to approach learning, objective instruments are needed. The learners, the family, and the educational system all have to spend a considerable amount of time and effort in arriving at a workable solution of this problem. Thus, an objective multiple intelligences inventory could help make decisions according to the individual's preference at such points.

\section{Gardner's Multiple Intelligences Theory}

Gardner proposed a much broader view of the definition of intelligence than a number of other theorists with his theory of multiple intelligences. He originally listed seven core intelligences: linguistic, logical-mathematical, spatial, bodily-kinaesthetic, musical, interpersonal and intrapersonal in Frames of Mind (2004). At the symposium "MIND 97" (Multiple Intelligences New Directions) in 1997, he added "Naturalist" intelligence in his list.

School curriculums have traditionally focused on the logical-mathematical and linguistic intelligences. Therefore, schools teach more effectively for the learners who have strong language and logical thinking skills. To ensure that other learners are not left behind, Gardner (1993) suggests that educational methods should be created and adjusted to be more flexible for learners who have different intellectual capacities, and should be re-designed and rearranged to use the multiple intelligences effectively so that those changes would benefit learners, teachers and society.

Thomas Armstrong (2000) listed four points to display the key ideas of Gardner's Multiple Intelligences theory. First, each person possesses capacity in all intelligences. Some people perform extremely high levels of functioning in all intelligences while others tend not to display many. Most of us however, appear to possess some highly developed intelligence as well as some weak ones. Second, most people have the capacity to develop each intelligence to an adequate level of competency. The combination of the environmental influences such as school instruction, parents, and exposure to cultural activities can strengthen or can weaken certain intelligence. If given appropriate instruction and encouragement, all intelligences can develop and reach to a higher level. Third, intelligences usually work together in complex ways. No intelligence works alone because intelligences always interact with each other. For example, to make a cake, one should read the recipe, weigh the flour, and decide the flavour to satisfy all members of the family and one's own preference. The process of making a cake needs the intelligences such as linguistic, logical-mathematical, interpersonal, and intrapersonal intelligences. Fourth, there are many ways to be intelligent within each category. In other words, one can perform each intelligent in different ways. For example, a bodily-kinaesthetic person cannot dance well, but is highly bodily-kinaesthetic because he can make manual products well.

Based on Gardner's theory, Chapman and Freeman (1996) emphasize three implications that are useful for educational system. Firstly, intelligence can be taught or at least enhanced through teaching. Secondly, intelligences are changing throughout life. Thirdly, the existence of different intelligences that different learners 
possess results in different learning styles and different needs. Hence Chapman (1993) suggests several implications of Gardner's theory which are relevant for English teachers. The implications are (1) everyone has at least an intelligence of strength, (2) everyone has some weaker intelligence that can cause discomfort, (3) weakness can be strengthened, and (4) one's brain is as unique as a fingerprint.

These ideas suggest that teachers may need to ensure that their classroom teaching practices and programmes, take account of the different multiple intelligences of learners and the learning styles associated with each. In this way the particular and the different strengths of learners will be accommodated.

\section{Multiple Intelligences and Learner Profiles}

Apparently each and every one of the learners possesses at least an intelligence of strength. Thus, they represent different profiles for the whole class. To get a clear picture of learner profiles within the context of multiple intelligences, works by Armstrong (2000), Chapman (1993) and Gardner (1993, and 2004) could guide teachers (see Table 1). It is important to identify individual learner profiles as it will constitute to class profiles. By knowing individual learner profiles and class profiles, teachers are able to decide on appropriate teaching strategies and learning activities for the class. If the class are strong in interpersonal intelligence, then teachers may adopt teaching strategies of cooperative learning and games and design learning activities that encourage learners to involve in high challenge, cooperative learning situations in the classroom such as group games.

\section{'Insert Table 1: Gardner's Multiple Intelligences'}

\section{Multiple Intelligences and Learning Styles}

Since learners have different intelligences, definitely they own different learning styles or preferred ways of approaching learning. Some learners may find that they have a preferred style of learning or way of encountering the world and less use or experience with other styles. Others may find that they use different styles in different situations. As a teacher, we need to know learners' learning preferences (see Table 2), help them to make good use of their learning styles, and develop ability in less dominant ones (Armstrong, 2000). Some learners used to think in words, or by reasoning, or in images and pictures, or through somatic sensation, or via rhythms and melodies, or by bouncing ideas of other people, or simply think deeply inside of themselves. Learning styles according to multiple intelligences point of view can be classified into visual learners, auditory learners and kinaesthetic learners (Gardner, 2004). Visual learners learn information mainly through the eyes. They need to see the teacher's body language and facial expression to fully understand the content of a lesson. They learn best from visual displays. They often prefer to take detailed notes to absorb the information. Auditory learners learn best through verbal lectures, discussion, talking things through and listening to what others have to say. They interpret the underlying meaning of speech through listening to tone of voice, pitch, speed and other nuances. To them, written information might have little meaning. They often benefit from reading text aloud and using audio equipment. For kinaesthetic learners, they learn best through hands-on approach, actively exploring the physical world around them. They might find it hard to sit still for long periods and might become distracted. Thus, teachers need to present information using different styles. This variety in presentation of content and overall instructional approach allows learners to learn better and more quickly especially if the chosen teaching methods used better match their preferred learning styles. Besides, learners can also learn in other ways and not just in their preferred styles.

Even though many studies on matching learning styles to teaching are suspect with unreliable measures and inflated claims, there are some values of considering learners' learning styles (Coffield, et al., 2004; Rosenfeld \& Rosenfeld, 2004). First, by helping learners think about their learning styles and learning preferences, teachers can develop the value of self-monitoring and self-awareness for learning and motivation. Second, by looking at individual learner's approaches to learning, teachers will appreciate, accept, and accommodate learner differences.

\section{'Insert Table 2: Learning Preference' \\ Multiple Intelligences and Language Learning}

The value of knowing one's strength and weakness in different intelligences is that they can make some efforts to excel or improve themselves in intended areas. Armstrong (2000) has proposed some learning activities, which are based on multiple intelligences to help learners in their language learning (see Table 3). Certain learning activities can stimulate certain intelligences, such as reading English newspaper everyday can stimulate learners' linguistic intelligence. However, Gardner (1993) indeed suggests that during a learning episode it will be normal for a number of intelligences to be used together.

'Insert Table 3: Learning Activities' 


\section{Multiple Intelligences and Language Teaching}

Multiple Intelligences theory can be described not only as a philosophy or an attitude toward learning but as possible techniques to be developed in the classroom as well. A teacher's role in an MI classroom contrasts sharply with that of a teacher in a traditional classroom. In the traditional classroom, the teacher lectures while standing at the front of the classroom, writes on the board, questions learners about the assigned readings or handouts, and waits as learners finish their written work. In comparison, in the MI classroom, the teacher continually shifts method of presentation from linguistic to spatial to musical and so on. Teachers can also combine intelligences in creative ways.

In teaching English, some strategies related to the development of communicative approach and competence based strategies can be applied by English teachers. Multiple intelligences theory opens the door to a wide variety of teaching strategies that can be implemented in the classroom to support the existing ones. The theory provides a road for accomplishing what good teachers have always done: reach beyond the text to make varied chances available for learners to learn and show evidence in learning. It allows a framework for teachers to reflect on their best teaching methods and to understand why these methods work. It also assists teachers expand their teaching repertoires to include a broader range of methods, materials, and techniques for reaching an ever-wider and more diverse range of learners (Hatmanto, 2004). In an MI classroom, learners learn best through their areas of smartness or intelligence.

Using Gardner's Multiple Intelligences, Lazear (2004) recommends intelligence profiles for learners (see Table 1). These profiles provide teachers with new knowledge about how to help all learners regardless of their relative strengths and weakness in the various intelligence areas to get more out of school. He also has invented Multiple Intelligences Toolbox from Eight Ways of Knowing which includes a set of easily integrated teaching strategies and ideas for moving lessons to multiple levels (see Table 4). For instance, an English teacher may design his or her lesson that incorporates reading, drawing a mind map and group presentations to help learners develop their linguistic, logical-mathematical and interpersonal intelligences.

\section{'Insert Table 4: Integrated Strategies'}

\section{Conclusion}

No one learner is alike and teachers must realize that a single teaching method fit for all will not work in a classroom. Therefore, Gardner (1993) suggests that educational methods should be created and adjusted to be more flexible for learners who have different intellectual capacities. A learner's strength in a particular intelligence has to be identified from the onset to enable teachers to suit their teaching styles according to the intelligences and learning preferences of each individual learner. Multiple intelligences theory gives teachers an opportunity to use integrated strategies which include various learning activities to fit learners of different intelligence profiles, learning styles and learning preferences in classroom teaching. Besides, teaching through multiple intelligences has been found to increase interest and achievement in classroom assessment (Greenhawk, 1997; Kornhaber, Fierros, \& Veenema, 2003; Saban, 2000; Yilmaz \& Fer, 2003). As a conclusion, English language teaching and learning through multiple intelligences that suit individual differences, and diverse learning styles and learning preferences should be enhanced in order to produce quality learners.

\section{References}

Armstrong, T. (2000). Multiple intelligences in the classroom (2 $2^{\text {nd }}$ ed.). Alexandria, VA: ASCD.

Birney, D., Citron-Pusty, J., Lutz, D., \& Sternberg, R. (2005). The development of cognitive and intellectual abilities. Mahwah, NJ: Erlbaum.

Chapman, C. (1993). If the shoes fit: How to develop multiple intelligences in the classroom. Palatine, IL: IRI/Skylight Training and Publishing.

Chapman, C., \& Freeman, L. (1996). Multiple intelligence: Centers and projects. Arlington Height, IL: IRI/Skylight Training and Publishing.

Coffield, F., Moseley, D., Hall, E., \& Ecclestone, K. (2004). Learning styles and pedagogy in post-16 learning: A systematic and critical review. London: Learning and Skills Research Centre, University of Newcastle upon Tyne.

Gardner, H. (1993). Multiple intelligences: The theory in practice. New York: Basic Books.

Gardner, H. (1999). Intelligence reframed multiple intelligences for the 21st century. New York: Basic Books.

Gardner, H. (2000). Intelligence reframed. New York: Basic Books. 
Gardner, H. (2004). Frames of mind: The theory of multiple intelligences ( $2^{\text {nd }}$ ed.). New York: Basic Books.

Greenhawk, J. (1997). Multiple intelligences meets standards. Educational Leadership , 62-64.

Gregory, R. (2007). Psychological testing (5th ed.). Boston: Allyn \& Bacon.

Hatmanto, E. (2004, October). Seminar on applying multiple intelligences approach in teaching English. Retrieved January 25, 2009, from American Corner Web Site

Kornhaber, M., Fierros, E., \& Veenema, S. (2003). Multiple intelligences: Best ideas from research and practice. In B. Shearer, MI at 25: Assessing the impact and future of multiple intelligences for teaching and learning. New York: Teachers College Press.

Lazear, D. (2004). Multiple intelligences approaches toaAssessment. Wales, UK: Crown House Publishing Ltd.

Rosenfeld, M., \& Rosenfeld, S. (2004). Developing teachers sensitivities to individual learning differences. Educational Psychology, 24, 465-486.

Saban, A. (2000). Toward a more intelligent school. Educational Leaderships, 60, 71-73.

Santrock, J. (2008). Educational Psychology (3 ${ }^{\text {rd }}$ ed.). New York: Mc-Graw Hill.

Spearman, C. (1927). The abilities of man. New York: Macmillan.

Steinberg, L. (2006, April). A new approach to the study of adolescent cognitive development. Paper presented at the meeting of the Society for Research on Adolescent Development. San Francisco.

Sternberg, R. (1986). Intelligence applied. Fort Worth, TX: Harcourt Brace.

Sternberg, R. (2002). Intelligence: The triarchic theory of intelligences. In J.W. Gutherie (Ed.), Encyclopedia of education ( $2^{\text {nd }}$ ed.). New York: Macmillan.

Sternberg, R. (2004). Individual differences in cognitive development. In P. Smith \& C. Hart (Eds.), Blackwell handbook of cognitive development. Malden, MA: Blackwell.

Sternberg, R. (2006). Cognitive psychology (4th ed.). Belmont, CA: Wadsworth.

Thurstone, L. (1938). Primary mental abilities. Chicago: University of Chicago Press.

Yilmaz, G., \& Fer, S. (2003). The students' opinion and achievement concerning instructional activities based on multiple intelligences theory. Hacettepe Universitesi Egitim Fakultesi Dergisi, 25, 235-245. 
Table 1. Gardner's Multiple Intelligences

\begin{tabular}{|c|c|c|}
\hline INTELLIGENCE & DESCRIPTION & LEARNER PROFILE \\
\hline Linguistic & $\begin{array}{l}\text { ability to use language effectively and creatively to } \\
\text { communicate ideas both in writing and speaking }\end{array}$ & $\begin{array}{l}\text { - have a good vocabulary } \\
\text { - like getting into involved discussions, debating, } \\
\text { formal speaking, creative writing } \\
\text { - like to read books and always seem to be absorbed } \\
\text { in books }\end{array}$ \\
\hline Musical & $\begin{array}{l}\text { ability to recognize and use the nonverbal sounds: pitch, } \\
\text { rhythms, and total patterns }\end{array}$ & $\begin{array}{l}\text { - learn songs quickly } \\
\text { - like playing musical instruments } \\
\text { - like spending hours listening to music on the radio } \\
\text { or CDs }\end{array}$ \\
\hline Logical-Mathematical & ability to use numbers effectively and reasons well & $\begin{array}{l}\text { - excel in computer programming } \\
\text { - like to solve puzzles } \\
\text { - like to think }\end{array}$ \\
\hline Spatial & $\begin{array}{l}\text { ability to manipulate and perceive objects or forms } \\
\text { mentally and then to transfer those perceptions either } \\
\text { mentally or concretely }\end{array}$ & $\begin{array}{l}\text { - like working jigsaw puzzles } \\
\text { - able to read maps and find way around new places } \\
\text { - like to draw, paint, make interesting designs and } \\
\text { patterns, and work with clay, coloured construction } \\
\text { paper, and fabric }\end{array}$ \\
\hline Bodily-Kinaesthetic & ability to coordinate physical movement & $\begin{array}{l}\text { - enjoy acting or performing } \\
\text { - communicate well through body language and } \\
\text { other physical gestures } \\
\text { - like demonstrating how to do something }\end{array}$ \\
\hline Intrapersonal & $\begin{array}{l}\text { ability to process information about how a person feels } \\
\text { and thinks }\end{array}$ & $\begin{array}{l}\text { - introverts } \\
\text { - are highly self-reflective and self-aware } \\
\text { - are strong willed, self-confident, and have definite, } \\
\text { well-thought out opinions on almost any issue }\end{array}$ \\
\hline Interpersonal & $\begin{array}{l}\text { ability to process information about how other people are } \\
\text { feeling and thinking }\end{array}$ & $\begin{array}{l}\text { - extroverts } \\
\text { - communicate effectively } \\
\text { - empathize easily with others }\end{array}$ \\
\hline Naturalist & $\begin{array}{l}\text { ability to recognize and classify both the animal and } \\
\text { plant kingdom }\end{array}$ & $\begin{array}{l}\text { - love the outdoors activities } \\
\text { - are fascinated with the nature } \\
\text { - have an affinity and respect for all living creatures }\end{array}$ \\
\hline
\end{tabular}


Table 2. Learning Preference

\begin{tabular}{|c|c|c|c|}
\hline $\begin{array}{l}\text { CHILDREN WHO ARE } \\
\text { STRONGLY }\end{array}$ & THINK & LOVE & NEED \\
\hline Linguistic & in words & $\begin{array}{l}\text { - reading } \\
\text { - writing } \\
\text { - telling stories }\end{array}$ & $\begin{array}{l}\text { - books } \\
\text { - dialogue } \\
\text { - discussion }\end{array}$ \\
\hline $\begin{array}{l}\text { Logical- } \\
\text { Mathematical }\end{array}$ & by reasoning & $\begin{array}{l}\text { - experimenting } \\
\text { - questioning } \\
\text { - figuring out logical puzzles }\end{array}$ & $\begin{array}{l}\text { - things to explore } \\
\text { - science materials } \\
\text { - trips to the science museum }\end{array}$ \\
\hline Spatial & $\begin{array}{l}\text { in images } \\
\text { and } \\
\text { pictures }\end{array}$ & $\begin{array}{l}\text { - designing } \\
\text { - drawing } \\
\text { - visualising }\end{array}$ & $\begin{array}{l}\text { - imaginative games } \\
\text { - puzzles } \\
\text { - illustrated books }\end{array}$ \\
\hline Bodily-Kinaesthetic & $\begin{array}{l}\text { through somatic } \\
\text { sensations }\end{array}$ & $\begin{array}{l}\text { - dancing } \\
\text { - building } \\
\text { - gesturing }\end{array}$ & $\begin{array}{l}\text { - role-play } \\
\text { - drama } \\
\text { - things to build }\end{array}$ \\
\hline Musical & $\begin{array}{l}\text { via rhythms and } \\
\text { melodies }\end{array}$ & $\begin{array}{l}\text { - } \text { singing } \\
\text { - humming } \\
\text { - listening }\end{array}$ & $\begin{array}{l}\text { - sing-along sessions } \\
\text { - music playing } \\
\text { - musical instruments }\end{array}$ \\
\hline Interpersonal & $\begin{array}{l}\text { by bouncing ideas of } \\
\text { other people }\end{array}$ & $\begin{array}{l}\text { - leading } \\
\text { - organising } \\
\text { - relating }\end{array}$ & $\begin{array}{l}\text { - friends } \\
\text { - group games } \\
\text { - clubs }\end{array}$ \\
\hline Intrapersonal & $\begin{array}{l}\text { deeply inside of } \\
\text { themselves }\end{array}$ & $\begin{array}{l}\text { - } \text { setting goals } \\
\text { - dreaming } \\
\text { - being quiet }\end{array}$ & $\begin{array}{l}\text { - time alone } \\
\text { - self-paced projects } \\
\text { - choices }\end{array}$ \\
\hline
\end{tabular}


Table 3. Learning Activities

INTELLIGENCE

Linguistic

Logical-Mathematical

Spatial

Bodily-Kinaesthetic

Intrapersonal

Interpersonal

Naturalistic

\section{LEARNING ACTIVITIES}

- read English books or magazines just for the fun of it

- read English newspaper every day

- memorize a favourite song, poem or story

- listen to different kinds of music

- sing English songs in the shower

- turn some of the learning into a song or rhythmic chant

- watch television shows about science

- read about detective stories

- play logical-mathematical games

- work on jigsaw puzzles involving language

- cut out favourite pictures from magazines and make a collage

- pay close attention to the television advertisement, films seen

- put on music with songs and make up own creative dance to reflect words

- enrol in a dance, drama or poetry class

- learn cooking, gardening, woodworking

- think about ones goals and hopes for the future

- record ones thoughts and feelings in a daily journal

- list strength and weakness in language learning

- join English club at school

- meet and talk English with one new person every month

- interact with at least one person out of class in English every day

- collect flowers or other natural things to show and describe to friends

- enjoy studying environment, nature, plants, and animals

- talk about favourite pets or preferred natural places to friends 
Table 4. Integrated Strategies

\section{INTELLIGENCE} PROFILE

\section{Linguistic}

Bodily-Kinaesthetic

Interpersonal

Intrapersonal

Naturalist

TEACHER'S TASK

DESIGN LESSON THAT

INCORPORATE

encourage learners to develop fully and refine their verbal-linguistic abilities

encourage learners to develop fully and use their logical thought processes

encourage learners to express their thoughts through pictures, images, symbols, colours, designs, and patterns

encourage learners to take part in hands-on activities

encourage learners to explore the sound, music, and rhythmic dimensions of lessons

encourage learners to involve in high-challenge, cooperative learning situations in the classroom

encourage learners to explore their inner feelings and thought

encourage learners to express their ideas, thoughts, and feelings through natural metaphors, similes, and analogies
- reading

- formal speaking

- journal or diary keeping

- outlining

- graphic or cognitive organizers

- problem solving

- visualizing

- active imaginations

- diagrams, illustrations flowcharts

- role-playing or mime

- dramatic enactment

- inventing

- vocal sounds or tones

- music composition or creation

- rapping

- giving feedback

- cooperative learning strategies

- person-to-person communication

- silent reflection methods

- thinking strategies planning

- independent studies and projects

- natural world encounters

- growing things

- environmental sensitivity 